\title{
Report of Resistant Varicella Zoster infection treated with Donor Lymphocyte Infusion in a Pediatric Oncology Patient
}

Dol:

10.1097/INF.0000000000002252

\section{Document Version}

Accepted author manuscript

Link to publication record in Manchester Research Explorer

Citation for published version (APA):

Cooper, K., Makin, G., Davies, E., Turner, A., Hiwarkar, P., \& Wynn, R. (2019). Report of Resistant Varicella Zoster infection treated with Donor Lymphocyte Infusion in a Pediatric Oncology Patient. The Pediatric infectious disease journal. https://doi.org/10.1097/INF.0000000000002252

\section{Published in:}

The Pediatric infectious disease journal

\section{Citing this paper}

Please note that where the full-text provided on Manchester Research Explorer is the Author Accepted Manuscript or Proof version this may differ from the final Published version. If citing, it is advised that you check and use the publisher's definitive version.

\section{General rights}

Copyright and moral rights for the publications made accessible in the Research Explorer are retained by the authors and/or other copyright owners and it is a condition of accessing publications that users recognise and abide by the legal requirements associated with these rights.

\section{Takedown policy}

If you believe that this document breaches copyright please refer to the University of Manchester's Takedown Procedures [http://man.ac.uk/04Y6Bo] or contact uml.scholarlycommunications@manchester.ac.uk providing relevant details, so we can investigate your claim.

\section{OPEN ACCESS}




\section{The Pediatric Infectious Disease Journal Publish Ahead of Print}

DOI: 10.1097/INF.0000000000002252

Report of Resistant Varicella Zoster infection treated with Donor Lymphocyte Infusion in a

\section{Pediatric Oncology Patient}

Katherine Cooper, $\mathrm{MBChB}, \mathrm{MRCPCH}^{1}$, Guy Makin, BM,BCh, PhD, MRCP, FRCPCH${ }^{2}$, Emma

Davies, $\mathrm{MSc}^{3}$, Andrew Turner, MBChB FRCPath ${ }^{3}$, Prashant Hiwarkar, MBBS, MD, PhD,

$\mathrm{FRCPCH}^{4}$, and Robert Wynn, BA, MB BChir, MD, MRCP FRCPath ${ }^{4}$

1. Department of Paediatric Oncology and Haematology, Alder Hey Children's Hospital

2.Department of Paediatric Oncology, Royal Manchester Children's Hospital, Manchester, UK

3. Department of Clinical Virology, Manchester Royal Infirmary, Manchester, UK

4. Department of Paediatric Blood and Marrow Transplant, Royal Manchester Children's Hospital, Manchester, UK

Disclosures: The authors have no conflicts of interest or funding to disclose

Abbreviated Title: Resistant Varicella treated with Donor Lymphocyte

Running Head: Resistant Varicella treated with DLI

Corresponding Author: Dr Katherine Cooper, Oncology Department, Alder Hey Childrens

Hospital, Eaton Road, Liverpool, L12 2AP, klhorsnell@ doctors.org.uk

The authors have no conflict of interests

Informed consent was obtained and correctly documented for the use of the photographs in this report 


\section{Abstract}

We report an 8 year old boy with disseminated, life-threatening, drug treatment-resistant varicella zoster infection occurring during standard treatment for neuroblastoma in whom viral clearance and cure was effected by donor Lymphocyte infusion from his HLA-identical twin sibling.

Keywords: Varicella, Donor Lymphocyte, Pediatric Oncology

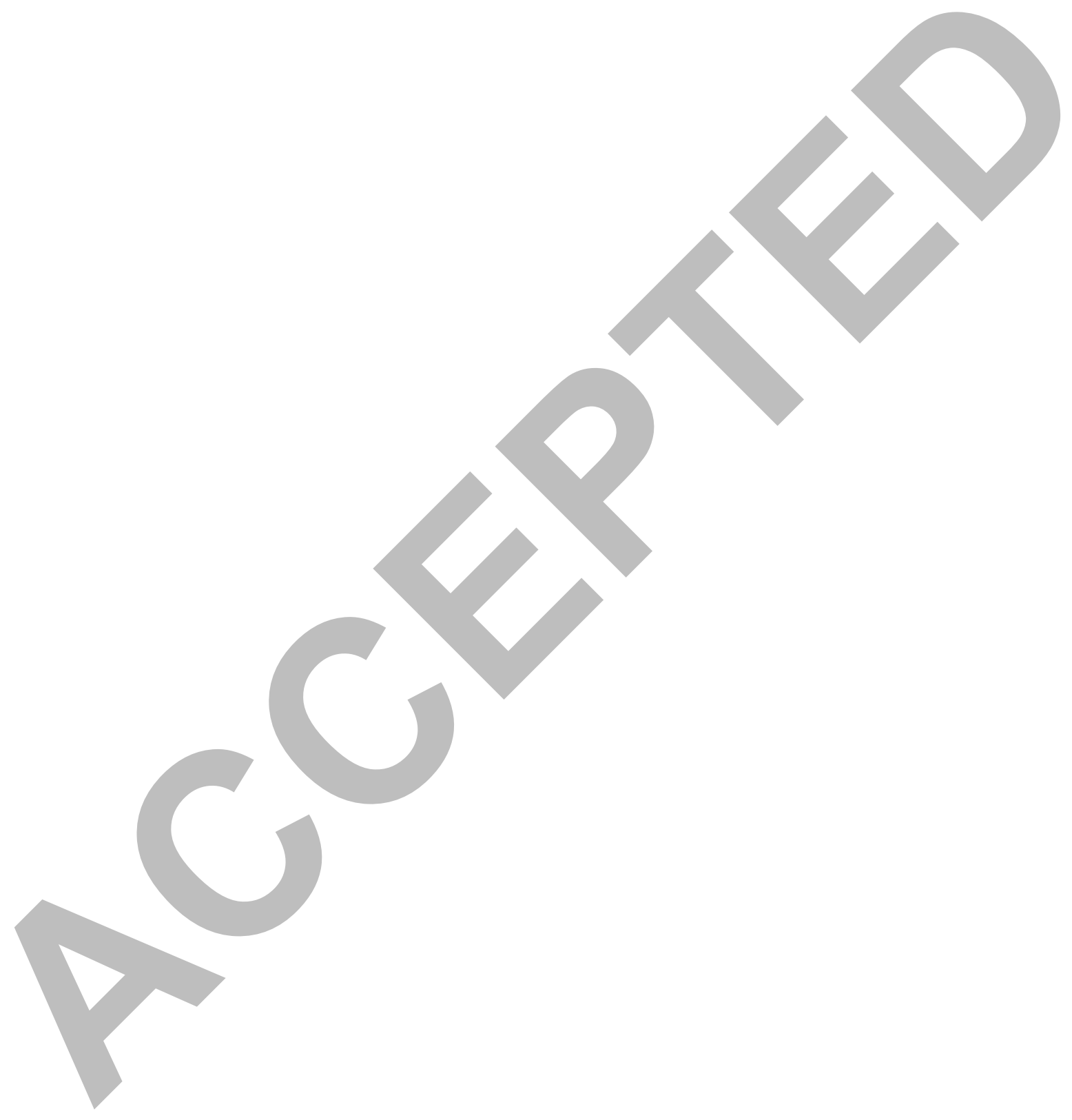


Introduction

Infection, including virus infection, is a major cause of mortality and morbidity during cancer chemotherapy. Varicella zoster virus infection has become a manageable infection with the advent of improved anti-viral drug therapy, but chronic illness with superficial lesions lasting for months and fatal disease dissemination is reported including in the context of increasing aciclovir drug resistance. $^{1-4}$

Reconstitution of virus-specific cell-mediated immunity in the immune compromised host is a therapeutic strategy to clear disease-causing virus where there is no drug therapy or where that therapy has been ineffective. This includes treatment of EBV, CMV and adenovirus infections after Haemopoietic Stem Cell Transplant (HSCT) where donor or third party allogeneic lymphocytes, including selected virus-specific T-cells have been used.

Case Description

We present an 8 year, $17 \mathrm{Kg}$, old boy with stage 4 neuroblastoma with bony metastases. He was enrolled for high risk neuroblastoma study R3 modified N7 as per national protocol. He tolerated 4 cycles of chemotherapy which consisted of 3 cycles of cyclophosphamide $(70 \mathrm{mg} / \mathrm{kg}$ on day 0 and 1), vincristine $(0.022 \mathrm{mg} / \mathrm{kg}$ for 3 days) and doxorubicin $(25 \mathrm{mg} / \mathrm{m} 2$ for 3 days $)$, and 1 cycle of cisplatin $(50 \mathrm{mg} / \mathrm{m} 2$ on days $0-3)$ and etoposide $(200 \mathrm{mg} / \mathrm{m} 2$ days $0-2)$. However 8 days after his 4 th cycle he was admitted with febrile non-neutropenic illness with a rash which was later proven to be varicella zoster virus from skin swab. His twin sister had simultaneous classical chicken pox infection at home.

He received 5 days of intravenous aciclovir $(500 \mathrm{mg} / \mathrm{m} 2)$ and all lesions resolved but he required similar, repeated therapy for recurrent skin lesions associated with fever. Two weeks later during a $5^{\text {th }}$ cycle of chemotherapy, which consisted of cisplatin, etoposide, he developed again skin lesions and again intravenous acyclovir $(500 \mathrm{mg} / \mathrm{m} 2)$ was started but the lesions persisted and developed ( Figure 1a). There was detectable VZV viraemia and he developed invasive disease. Specifically he required repeated drainage of a VZV-associated pericardial effusion associated with impaired 
cardiac function. Figure 2 details the clinical course of our patient, including the different drugs used, the viral load in blood, the deteriorating renal function associated with the drugs used and the need for cardiac interventions. There was clearly documented clinical drug resistance to therapeutic dose aciclovir. There was persistence and progression of skin lesions, continuing fever and a necessity for repeated cardiac intervention. There was no clinical response to altered antiviral therapies including foscarnet and cidofovir, and there was additionally identified a novel aciclovir resistance mutation in the virus isolate. Genotypic VZV resistance testing carried out on blood detected mixed population consisting of wild type VZV and VZV T to $\mathrm{C}$ mutation at nucleotide 770 of the thymidine kinase gene resulting in a change of amino acid 257 from leucine to serine. There was also $\mathrm{A}$ to $\mathrm{C}$ mutation at nucleotide 76 of the thymidine kinase resulting in a change of amino acid 26 from threonine to proline. These mutations have not previously been described in literature. Despite interruption of chemotherapy the patient remained lymphopenic, with persistent, drugresistant viraemia and marked drug-related toxicity. The patient's life was threatened in multiple ways - by the VZV directly, by our inability to adequately treat his cancer, and by the organ damage specifically renal impairment, associated with drug therapies. We therefore elected to use experimental, cell-mediated therapy. His twin was shown to be HLA-identical and we gave 5 x $10^{6}$ /kg CD3 positive T-cells from her, taken by venesection, given as a fresh donor lymphocyte infusion (DLI), and after regulatory approval. After this DLI the viral load dropped from log 3.7e10 to undetectable within 6 weeks and his skin lesions resolved (see Figure 1B). We were also able to show improved $\mathrm{T}$ cell numbers in the peripheral blood, and that these T-cells were of donor rather than autologous origin using short tandem repeat (STR) analysis, distinguishing donor from recipient DNA in a selected T-cell population taken from patient blood in the weeks following infusion. Antiviral therapies were stopped and the patient has gone on to receive high dose therapy for his neuroblastoma with stem cell rescue, from this same HLA-identical sibling donor. His VZV viral blood load has remained undetectable on twice weekly samples through his subsequent clinical 
course. There were no complications of his T-cell therapy and donor T-cells persisted until conditioning therapy for HCT.

\section{Discussion}

DLI is adoptive immunotherapy in which virus-specific donor cytotoxic $\mathrm{T}$ lymphocytes are transferred to patients, resulting in the elimination of virus-infected cells. Donor Lymphocytes were first used to treat leukaemia relapse after allogeneic haematopoietic stem cell transplant ${ }^{9}$. DLIs have also been successfully used for serious viral infections such as Epstein-Barr virus and adenovirus mostly post allo-HSCT ${ }^{10}$.

In this report we demonstrate clinical and virological response to unmanipulated, HLA-matched DLI in drug-resistant, clinically-refractory, life-threatening VZV infection. We were able to show donor-derived T-cell expansion in the blood of the patient at the same time as there was this clinical and virological response. The importance of DLI is that the mode of action is clearly distinct from that of the failing anti-viral therapy. It can therefore be effective, as in this case, where that therapy has failed due to mutated, drug-resistant virus, or is associated with drug-related toxicities. DLI is not without risk and its risk profile should be carefully considered before administration. In this instance the allogeneic T-cells were not rejected because of the immune suppression of the recipient by previous chemotherapy.

There are the risks associated with allogeneic cell therapy, including virus transmission. These risks are minimised through careful donor selection and appropriate virological testing. A major risk is graft versus host disease (GVHD), in which the infused T-cell population recognises not the virus but host tissues. Third party GVHD might indeed be a fatal illness. The risk of such GVHD is reduced in this instance by using an HLA-matched sibling donor in which there is expected to be fewer allo-reactive T-cells, and by using a relatively modest T-cell dose, which will limit the likelihood of administration of alloreactive T-cells. In other circumstances then the risk of DLIassociated GVHD is reduced by selecting for virus-specific T-cells. This might be done either through prolonged expansion of T-cells during culture with virus antigen or selecting from donor 
blood only those cells that secrete gamma interferon on exposure to virus antigen. These processes will select only those cells recognising virus and will therefore deplete allo-reactive cells and has been used to generate EBV-specific "off the shelf" partially HLA-matched cell banks for use in EBV-driven lymphoproliferative disease after solid organ transplant or after HSCT. These technologies were either not available in our acutely sick paediatric patient infected with VZV. As aciclovir resistance is reported as increasing, alternative treatments will be required with increased frequency particularly in immunocompromised patients. We report successful treatment of varicalla zoster virus with DLI which uses a mode of action that is clearly distinct from the increasingly failing anti-viral therapy. 


\section{References}

1. Dunkle LM, Arvin AM, Whitley RJ, Rotbart HA, Feder HM Jr, Feldman S, Gershon AA, Levy

ML, Hayden GF, McGuirt PV, et al. A controlled trial of acyclovir for chickenpox in normal children. N Engl J Med. 1991 Nov 28;325(22):1539-44.

2. Piret J, Boivin G. Antiviral drug resistance in herpesviruses other than cytomegalovirus. Rev Med Virol 2014; 24: 186-218.

3. Piret J, Boivin G. Antiviral resistance in herpes simplex virus and varicella-zoster virus infections: diagnosis and management Current Opinion in Infectious Diseases 2016. 29(6):654-662, December 2016.

4. Mullane KM, Nuss C, Ridgeway J, Prichard MN, Hartline CB, Theusch J, Mommeja-Marin H, Larson RA. Brincidofovir treatment of of acyclovir resistant disseminated varicella zoster virus infection in an immunocompromised host. Transpl Infect Dis. 2016 Oct;18(5):785-790. doi: 10.1111/tid.12583. Epub 2016 Sep 16.

5. Leen AM, Heslop HE, Brenner MK. Antiviral T-cell therapy. Immunol Rev. 2014;258(1):12-29. 6. Doubrovina E, Oflaz-Sozmen B, Prockop SE, et al. Adoptive immunotherapy with unselected or EBV-specific T cells for biopsy-proven EBV+ lymphomas after allogeneic hematopoietic cell transplantation. Blood. 2012;119(11):2644-56.

7. Nicholson E, Peggs KS. Cytomegalovirus-specific T-cell therapies: current status and future prospects. Immunotherapy. 2015;7(2):135-46.

8. Naik S, Nicholas SK, Martinez CA, Leen AM, Hanley PJ, Gottschalk SM, Rooney CM, Hanson IC, Krance RA, Shpall EJ, Cruz CR, Amrolia P, Lucchini G, Bunin N, Heimall J, Klein OR, Gennery AR, Slatter MA, Vickers MA, Orange JS, Heslop HE, Bollard CM, Keller MD. Adoptive immunotherapy for primary immunodeficiency disorders with virus-specific T lymphocytes. J Allergy Clin Immunol. 2016 May;137(5):1498-1505.e1.

9. Chalandon Y, Passweg JR, Guglielmi C, et al. Early administration of donor lymphocyte infusions upon molecular relapse after allogeneic hematopoietic stem cell transplantation for 
chronic myeloid leukemia: a study by the Chronic Malignancies Working Party of the EBMT.

Haematologica. 2014;99(9):1492-1498. doi:10.3324/haematol.2013.100198.

10. Lankester A, Locateeli F, Bollard C et al. Will Post-Transplantation Cell therapies for Pediatric patients become standard of Care. Bilo Blood Marrow Transplant 21 (2015) 402-11 
Figure 1a

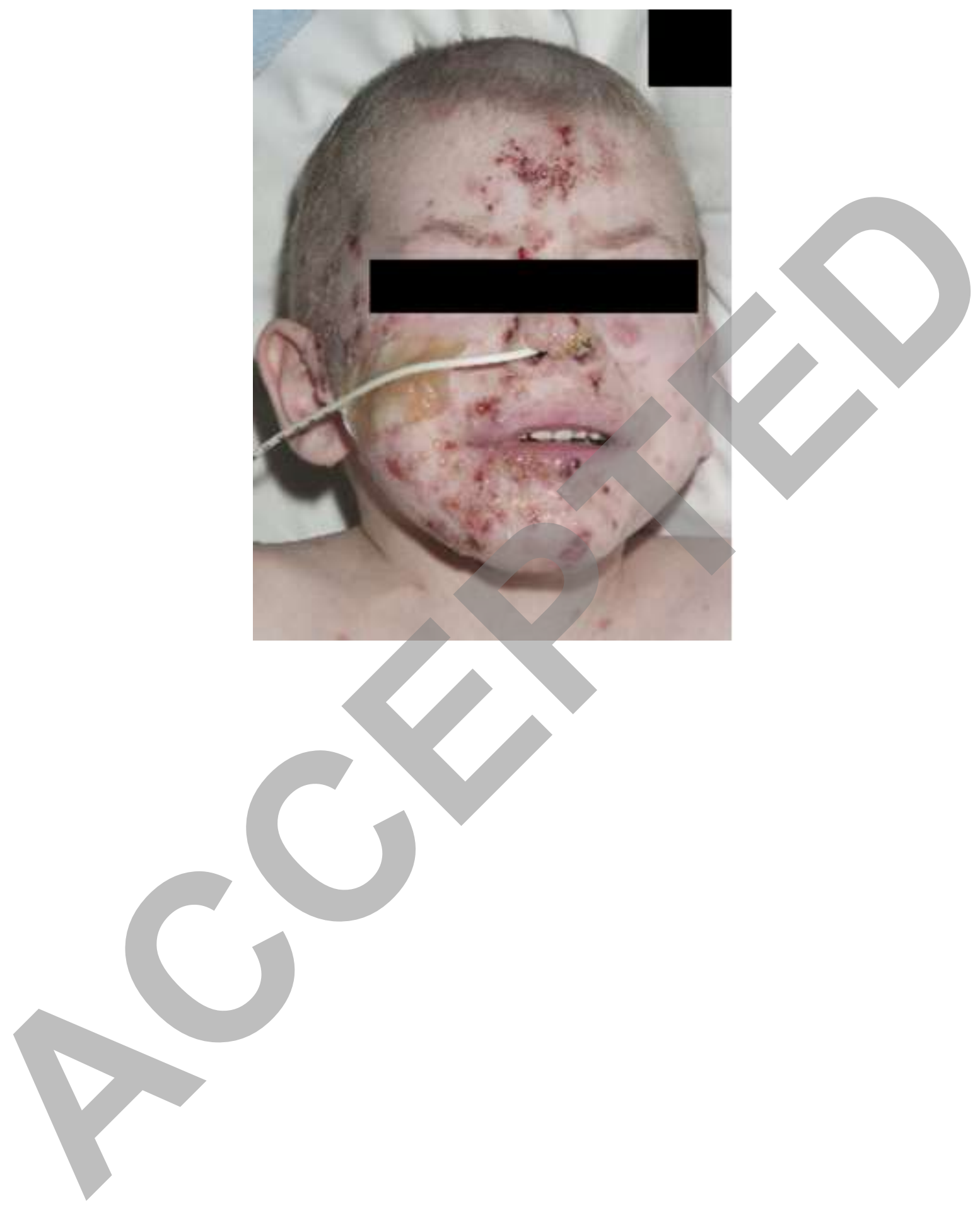

Copyright (C) 2018 Wolters Kluwer Health, Inc. Unauthorized reproduction of this article is prohibited. 
Figure 1b

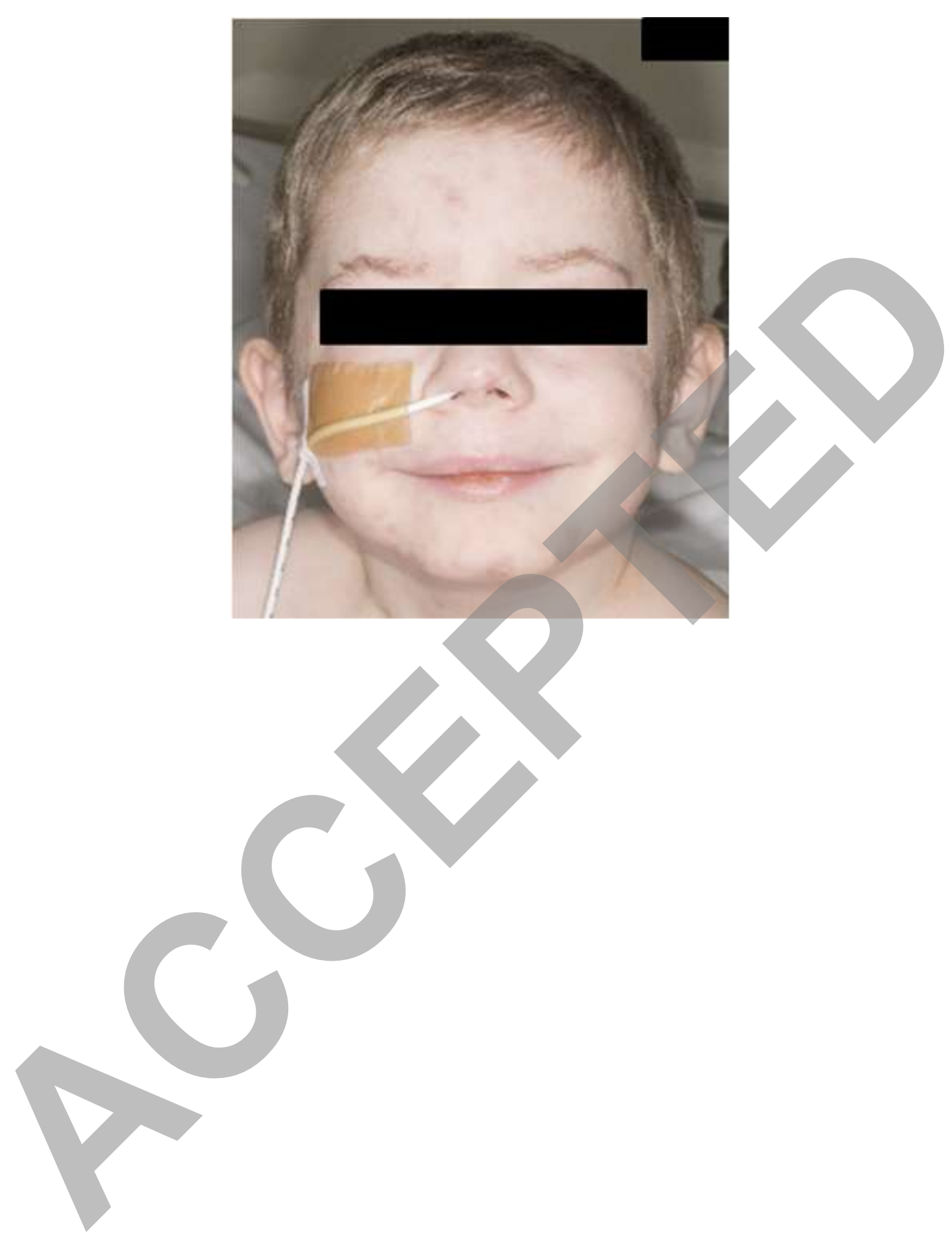

Copyright (C) 2018 Wolters Kluwer Health, Inc. Unauthorized reproduction of this article is prohibited. 
Figure 2

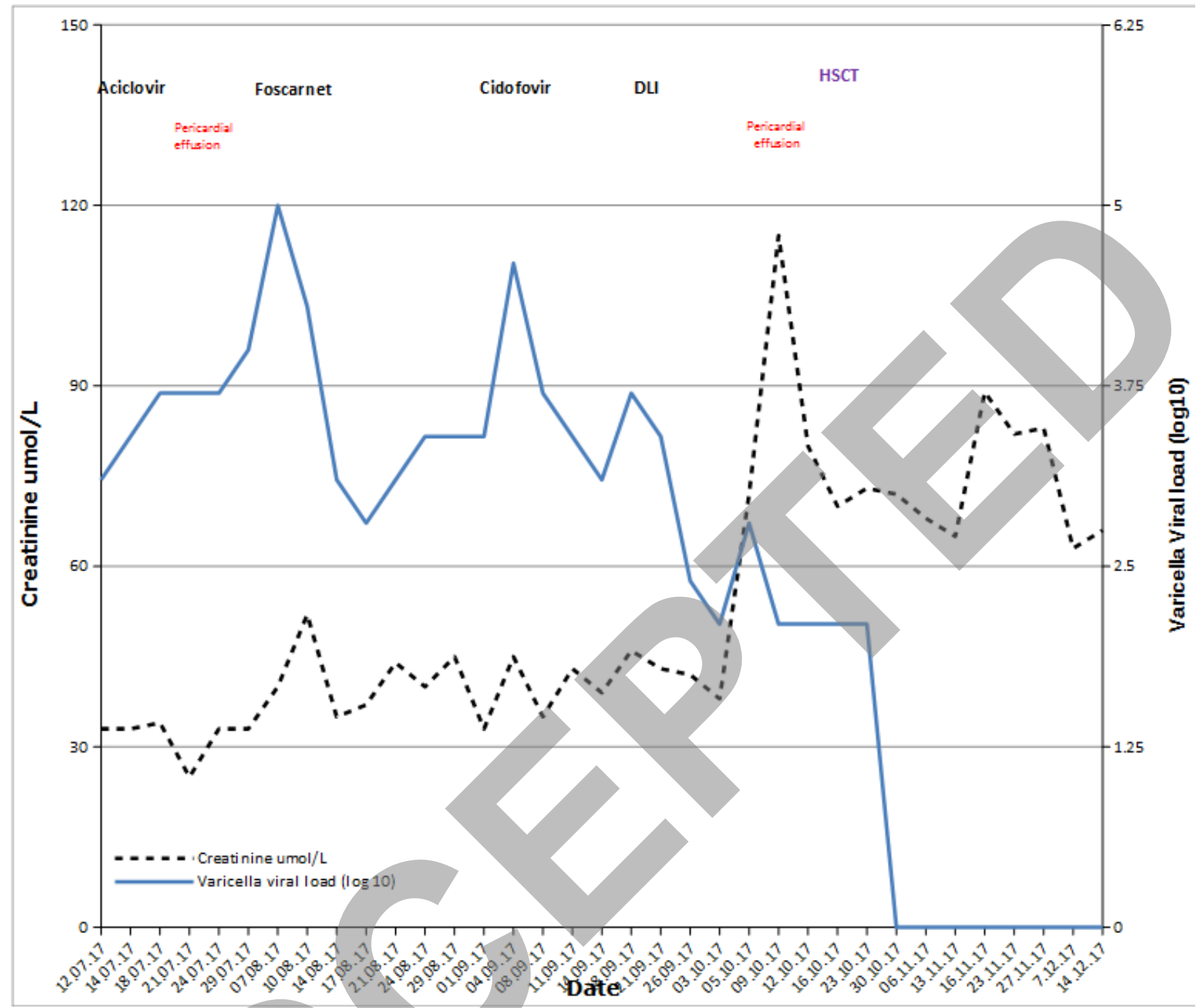

